\title{
Reconceptualising undergraduate entrepreneurship education at traditional South African universities
}

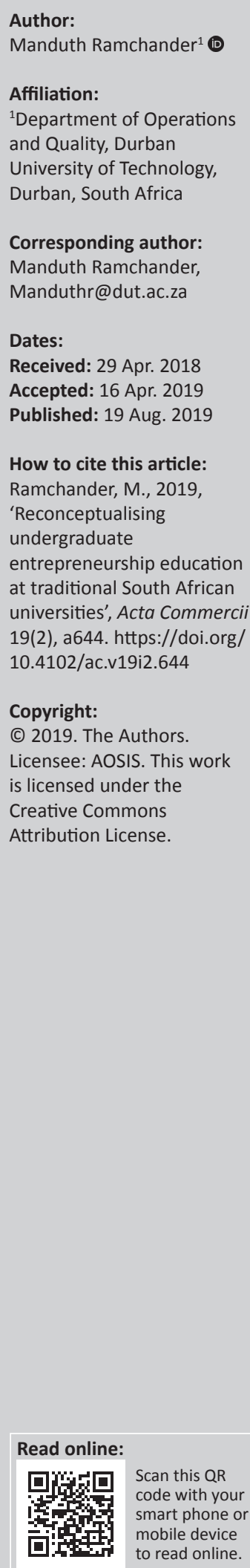

Orientation: The relatively high number of unemployed graduates in South Africa is a major cause for concern. Entrepreneurial start-ups have been heralded as the panacea to the unemployment challenge.

Research purpose: The aim of this study was to ascertain how entrepreneurship education, at traditional South African universities, measured against existing entrepreneurship education frameworks.

Motivation for the study: Despite a plethora of entrepreneurship education initiatives, the South African higher education system fails to produce sufficient entrepreneurs; hence, the need to explore how entrepreneurship education is structured.

Research design, approach and method: The research design was exploratory and both quantitative and qualitative in nature. The population comprised the eleven traditional universities in South Africa and all of them were included in the study. Secondary data was obtained from the respective universities' websites. The search sequence in the websites were as follows: Faculty of commerce/Management Sciences, Year/handbook, undergraduate/ postgraduate programmes. The word 'entrepreneurship' was also used as a keyword to search within the university website.

Main findings: The findings revealed some entrepreneurship modules, with low total credit value in relation to total programme credit value, at the undergraduate level and specialisation at the postgraduate level with some form of centre or incubator initiatives. It was also found that little attention is given to the development of entrepreneurial skills such as perseverance, resilience and self-efficacy.

Practical/managerial implications: The significance of this article lies in its potential to guide the reconceptualisation of entrepreneurship education at South African universities.

Contribution/value-add: This study integrates an existing framework and model to reconceptualise the undergraduate entrepreneurship programme. The reconceptualised structure entails a programme where modules from other disciplines are integrated into an entrepreneurship programme as opposed to the current structure where entrepreneurship modules are integrated into other career-focussed programmes.

Keywords: entrepreneurship; intention; opportunity; innovation; risk taking; identity; persistence; perseverance.

\section{Introduction}

South Africa's unemployment rate stands at 26.7\% (Statistics South Africa 2017), which is rather distant from the 14\% target espoused in the National Development Plan for 2020 and even further from the 6\% targeted for 2030 (National Planning Commission 2012). A compounding factor is the increasing enrolments at higher education institutions coupled with the relatively high numbers of unemployed graduates who are not able to secure employment in the formal sector (Muofhe and Du Toit 2011; Nel \& Neale-Schutte 2013). Neither the public sector nor the private sector has the capacity to absorb graduates (Fatoki 2010) and, consequently, entrepreneurial start-ups have been encouraged as the panacea to the unemployment challenge in South Africa (Chimucheka 2014; Kabonga \& Okpara 2010).

Collet (2013) contends that entrepreneurship education should enhance entrepreneurial intentions to influence individuals to start a business. Along similar lines, Abebe (2015) posits that entrepreneurship education should bring about a mind-set shift among graduates from job seekers to job creators. However, a relatively recent study involving 400 South African final year 
undergraduate students in commerce, law and management, engineering and the built environment, health sciences and the humanities (Urban \& Richard 2015) found that students had low levels of entrepreneurial intentions, with them preferring to be employed. Equally noteworthy, despite a plethora of entrepreneurship initiatives in higher education, the Global Entrepreneurship Monitor report (2017) has revealed that in comparison to other sub-Saharan African countries, South Africa records the lowest rate of total entrepreneurial activity of around $10.6 \%$.

It becomes apparent that the South African higher education system is not producing sufficient entrepreneurs and this could possibly be related to the way entrepreneurship programmes are structured and delivered. Hence, this article aims to explore how entrepreneurship education is organised at traditional universities in South Africa. The objective was to ascertain how entrepreneurship education, at traditional South African universities, measured against existing entrepreneurship education frameworks. The significance of this article lies in its potential to reconceptualise the structure of entrepreneurship education to produce entrepreneurs by design. In doing so, a reconceptualised framework for entrepreneurship education would serve as a point of departure and an enabler that could contribute to the reduction of particularly youth unemployment in South Africa.

\section{Literature review}

While this article relates to entrepreneurship education, it would be remiss not to include a discussion on how entrepreneurship links to economic growth. As early as 1911, Schumpeter's theory of economic development positions entrepreneurs as agents of change, through the creation of new businesses that provide the engine for economic advancement (Audretsch, Keilbach \& Lehmann 2006). Schumpeter's depiction of entrepreneurs as risk-taking, innovative agents of economic change (Zhang 2017) contrasts with Peter Drucker's (1985) contention that entrepreneurs are not necessarily the ones to cause change but those that respond to change exploiting them as opportunities. Drucker (1985) links innovation to change by using the phrase 'systematic innovation' intended to mean an organised and purposeful search for change accompanied by the systematic analysis of the opportunities therein.

To address some of the challenges of the 21st century, the World Economic Forum (2011) has launched a call for entrepreneurship to drive growth. Empirical evidence has long suggested that entrepreneurship positively influences growth in countries (Acs \& Amington 2004; Berkowitz \& Dejong 2005; Carree \& Thurik 2008) and, more recently, in African countries as well (Adusei 2016). Hence, the contention that entrepreneurship is central to the growth of economies (Baumol 2014; Zhang 2017), the promotion of innovation (Fritsch 2008) and, in some instances, the implementation of solutions for social upliftment (Littlewoo \& Holt 2018). It should also be noted that as entrepreneurship is synonymous with job creation (Folster 2000; Zhang 2017), several studies have used self-employment as a proxy measure of entrepreneurship (Bjuggren, Johansson \& Stenkula 2012; Rietvel, Hessels \& Zwan 2014).

Having discussed the contribution of entrepreneurship to the economy, it may be apt to define entrepreneurship. Schumpeter (1934) first defined entrepreneurship as the initiation of innovative activity and the offering of new products to markets. Some define entrepreneurship within the theme of opportunity. For example, entrepreneurship means an alertness towards profit opportunities (Kirzner 1978) or entrepreneurship is the process through which individuals identify opportunities to create value (Oluseye et al. 2017).

To understand the context of entrepreneurship, it is important to understand the inherent characteristics of an entrepreneur. In keeping with the definitions of entrepreneurship, entrepreneurs can be described as those that innovate, implement, take calculated risks and turn opportunities into profitable businesses (Robinson 2002). Along similar lines, Peter Drucker defines the entrepreneur as one who searches for change and responds to it, exploiting it as an opportunity (Dees, Haas \& Hass 1998). Johnson's (2001) definition includes the elements of creating novelty, managing risk and being persistent. Isah and Garba's (2015) definition also refers to innovativeness and includes the element of propensity for risk-taking. Thus, the key elements to entrepreneurship are innovation, opportunity recognition, propensity for taking risk and persistence.

Having defined entrepreneurship and the entrepreneur, the discussion now focuses on entrepreneurial behaviour. While there is no general agreement on the factors that drive entrepreneurial behaviour, several views stand in contrast with Von Mises's (1951) belief that money represents the only driver for entrepreneurial action in anticipation of a favourable outcome of an uncertain event. Schumpeter was of the view that the entrepreneur is not motivated by money but rather by the will for power and independence, the aim to triumph and the happiness of creating (Swedberg 2002). Similarly, Celuch, Bourdeau and Winkel (2017) contend that entrepreneurship makes it possible for people to exercise creative freedom, have higher self-esteem and a sense of control.

Chinyamurindi (2016) suggests that efforts could be channelled towards entrepreneurial education to encourage entrepreneurial intent. Entrepreneurial intention relates to an individual's willingness to pursue a course of action, considering the challenges of the task (Urban 2011). Hence, entrepreneurial intent is regarded as the immediate antecedent to entrepreneurial behaviour (Abebe 2015; Schlaegel \& Koenig 2014). Kuratko (2005) asserts that entrepreneurial intention can be developed because it is related to individuals' characteristics of seeking opportunity, taking risks and pushing an idea through.

The discussion now shifts to entrepreneurship education, which is central to this article. Despite earlier notions that 
entrepreneurs are born with the necessary innate skills, the literature abounds in evidence that entrepreneurship can be taught (Abebe 2015; Lebusa 2011; Panagiotis 2012; Skosana \& Urban 2014). Given the increasing recognition of entrepreneurship as an important economic force and premised on the notion that entrepreneurship education may serve as a springboard for economic growth, the expansion of entrepreneurship education has followed a similar trajectory, with the number of entrepreneurship-related courses being added to programmes at universities (Abebe 2015; Prior 2014). However, despite the growth in entrepreneurship education there has been criticism regarding the disjuncture between programmes and actual new ventures or entrepreneurial behaviour in real contexts (Donnellon, Ollila \& Middleton 2014) and the inability to apply learning beyond the classroom (Celuch et al. 2017).

The preference of South African graduates to seek employment rather than to be entrepreneurial is not unique. A study by Abebe (2015) involving 73 Ethiopian undergraduate natural, computational, social science, agricultural, business and economics, engineering and technology students found that the majority will be job seekers and unlikely to start their own business and the entrepreneurship courses attended had no significant influence in motivating students towards entrepreneurship. Another study involving 234 Malaysian undergraduate and postgraduate information technology, administration, management, education, English and tourism students found that students are focussed on completing the studies that they enrolled for and are not willing to take on good business opportunities that come their way (Sandhu, Jain \& Yusof 2010). Farrington, Gray and Sharp's (2011) study goes to the extent of suggesting that students have distorted views of what a career in entrepreneurship entails and students do not have sufficient skills and knowledge about starting a business.

The ensuing discussion presents an overview of entrepreneurship education in the United States and the United Kingdom. In their study, Nieuwenhuizen et al. (2016) found that entrepreneurship is not offered as a separate programme, but is included in most programmes as an elective across the institution and as a major in some programmes. Entrepreneurship-focussed programmes are also offered through short courses and stand-alone workshops through entrepreneurship centres, small business development centres, incubators and business schools (Centre for Entrepreneurial Excellence 2014). A national survey that captured the landscape of entrepreneurship education in the United States found that entrepreneurship modules are offered within the business or management departments and are embedded within programmes without being housed within a department dedicated to entrepreneurship (Centre for Entrepreneurial Excellence 2014).

An early empirical study by Co and Mitchell (2006) found entrepreneurship education in South Africa to be at an embryonic stage with pedagogies and programmes designed largely along conventional lines. Musetsho and
Lethoko (2017) contend that institutions should embrace entrepreneurship education in a way that is different from traditional offerings and advocate the infusion of more entrepreneurial-related activities such as guest speakers, experiential learning, field trips and visiting established entrepreneurship ventures. Donnellon et al. (2014) stress that to stimulate entrepreneurship, the curriculum must extend beyond simulation to include actual venture creation. Nieuwenhuizen et al. (2016) recommend the international best practice of the complementary role of incubators and entrepreneurship education comprising elective modules at the undergraduate level and specialisation at the postgraduate level.

Professor Mthembu, a South African academic, is also averse to conceptualising entrepreneurship education as encapsulated in the 'best practice' approach and in an interview with University World News (Dell 2016) expressed the following alternate approach to structuring entrepreneurial education in South Africa:

- The need for emphasis on entrepreneurial education in the formative stages, starting from day 1.

- The need for a student initiated approach to entrepreneurship as opposed to a student centred approach organised and controlled by the lecturer.

- The need for practice to be followed by theory and not the other way around.

Hence, that which comes to the fore is to posit how best to conceptualise entrepreneurship education in South African higher education. To this end and in keeping with Mwasalwiba's (2010) contention that entrepreneurship education should be underpinned by a strong theoretical framework, the presentation of Morris and Kuratko's (2014) $5 C^{\prime}$ 's framework and Pretorius, Nieman and Van Vuuren's (2005) entrepreneurial performance model are being followed.

The 5C's framework that was initially suggested by Morris and Kuratko (2014) provides a useful framework to assist in designing entrepreneurship education. For the purposes of this article, the descriptors for each of the elements of the $5 C^{\prime}$ 's model have been rephrased as questions, as illustrated in Table 1.

The five construct elements of the $5 C^{\prime}$ s framework are conceptualisation, convictions, competencies, connections and character. The author is of the view that conceptualisation is the most critical element of the $5 C^{\prime}$ 's framework as decisions around conceptualisation are bound to have significant resultant impact on other elements. For example, if entrepreneurship education is structured around the 'best practice' configuration, then the conviction element is impacted in terms of how much learning can take place outside the classroom. Although Morris and Kuratko make mention of the importance of the facilitator under the conceptualisation element, in this adaptation the author has not included it in the descriptor as it was deemed to be more appropriately and adequately encompassed under the convictions element. 
Morris and Kuratko (2014) contend that a distinct set of competencies need to be developed for entrepreneurial behaviour and these are listed and described in Table 2.

Morris and Kuratko (2014) contend that such competencies are key to curriculum design as well as instrumental in assessing the outcomes of entrepreneurship education. It should be noted that many of the competencies mentioned align closely to the definitions of entrepreneurship, entrepreneurial behaviour and entrepreneurial intent discussed earlier.

In acknowledging that the creation of entrepreneurs may be dependent on efficient education models, Pretorius et al. (2005) suggest the following entrepreneurial performance (synonymous with entrepreneurship) $(E / P)$ model for entrepreneurial education:

$E / P=f[a F \times b M x(c E / S \times d B / S) \times(e A+f B / P)]$

TABLE 1: 5C's framework for entrepreneurship program design.

\begin{tabular}{ll}
\hline Element & Descriptors \\
\hline Conceptualisation & $\begin{array}{l}\text { How is the programme structured? (Academic unit? } \\
\text { Administrative unit? Venture? Innovation incubator? Platform } \\
\text { for transformation? Undergraduate level, postgraduate level?) } \\
\text { What does the programme try to achieve? } \\
\text { What is the creative edge of the programme design? }\end{array}$ \\
Convictions & $\begin{array}{l}\text { To what extent is learning classroom based, work based, } \\
\text { experiential? } \\
\text { What are the approaches to develop competencies (theory, live } \\
\text { project, case study, scenarios and simulation)? } \\
\text { What are the convictions of the facilitators? }\end{array}$ \\
& $\begin{array}{l}\text { What are the convictions of the students? } \\
\text { Competencies }\end{array}$ \\
$\begin{array}{l}\text { What informs curriculum design (knowledge, skills, attitudes, } \\
\text { values and behaviours to be developed)? } \\
\text { What are the outcomes and how will they be assessed? }\end{array}$ \\
$\begin{array}{ll}\text { Hownections does the programme connect with other programmes } \\
\text { across the institution? }\end{array}$ \\
$\begin{array}{l}\text { How do external persons or entities integrate into the } \\
\text { programme (industry experts in lectures)? }\end{array}$ \\
$\begin{array}{l}\text { Do those leading the programme take on conventional roles } \\
\text { (educator, administrator, mentor, grant seeker) or are they } \\
\text { academic entrepreneurs? }\end{array}$ \\
\hline
\end{tabular}

Source: Adapted from Morris, M.H. \& Kuratko, D.F., 2014, 'Building university 21st century entrepreneurship programs that empower and transform', in S. Hoskinson \& D.F. Kuratko (eds.), Innovative pathways for university entrepreneurship in the 21st century, advances in the study of entrepreneurship, innovation and economic growth, vol. 24, pp. 1-24, Emerald Publishing Limited, Bingley, UK

TABLE 2: Competencies necessary for entrepreneurial behaviour.

\begin{tabular}{|c|c|}
\hline Competency & Description \\
\hline $\begin{array}{l}\text { Opportunity recognition } \\
\text { and assessment }\end{array}$ & $\begin{array}{l}\text { Perceiving possibilities of a business venture and } \\
\text { evaluating its attractiveness }\end{array}$ \\
\hline Risk mitigation & Reducing the probability and potential impact of risk \\
\hline Vision & Articulating a compelling image inducing others to follow \\
\hline Perseverance & Sustaining goal direct action amid obstacles \\
\hline Creativity & Solving problems by relating variables for novel outcomes \\
\hline Resource leveraging & Accessing resources owned and controlled by others \\
\hline Value creation & Developing new products and services \\
\hline Resilience & Coping and striving in the face of adversity \\
\hline Self-efficacy & $\begin{array}{l}\text { Maintaining a sense of self-confidence regarding one's } \\
\text { own abilities }\end{array}$ \\
\hline Network creation & Developing social interaction skills \\
\hline Focus & $\begin{array}{l}\text { Balancing strategic direction versus the need to pursue } \\
\text { improvement }\end{array}$ \\
\hline
\end{tabular}

Source: Adapted from Morris, M.H. \& Kuratko, D.F, 2014, 'Building university 21st century Source: Adapted from Morris, M.H. \& Kuratko, D.F,, 2014, 'Building university 21st century (entrepreurship progams that empower and transform', in S. Hoskinson \& D.F. Kuratk (eds.), Innovative pathways for university entrepreneurship in the 21st century, advances in the study of entrepreneurship, innovation and economic growth, vol. 24, pp. 1-24, Emerald Publishing Limited, Bingley, UK where $E / P$ represents entrepreneurial performance; $F$ represents the abilities, skills and experience of the facilitator; $M$ represents motivation; $E / S$ represents entrepreneurial skills; $B / S$ represents business skills and knowledge; $A$ represents teaching approaches; $B / P$ represents business plan utilisation (part of learning approach) and $a-f$ are constants with values ranging from 0 to 1 .

The five construct elements of the $E / P$ model are therefore facilitator skills, motivation, content, teaching approach and business plan utilisation. The multiplicative nature of the model implies that any weakness in a particular construct will diminish the overall effectiveness of the entrepreneurship programme (Pretorius et al. 2005).

When the 5C's framework is compared with the E/P model, common construct elements emerge, as depicted in Table 3.

While there are construct elements common to both the $5 C^{\prime}$ s framework and the $E / P$ model, there are construct elements in one that are not in the other. The element of conceptualisation in the $5 C^{\prime}$ s framework does not link to any element in the $E / P$ model with regard to structure. Competencies in the $5 C^{\prime} s$ framework associate with $E / S$ and $B / S$ in the $E / P$ model. Convictions in the $5 C^{\prime} s$ framework associate with the facilitator, motivation, approach and business plan utilisation elements in the $E / P$ model. Approach in the E/P model could link to connections in the $5 C^{\prime}$ s framework.

With regard to teaching approaches $(A)$ in the $E / P$ model and the conviction construct in the $5 C^{\prime}$ 's framework, teaching can be categorised as teaching 'about', 'for' and 'through' entrepreneurship (Chang \& Rieple 2013; Lackeus 2015; Mwasalwiba 2010; Pittaway \& Edwards 2012). Teaching 'about' entails a theoretical and content-laden approach aimed to give a general understanding of a phenomenon (Mwasalwiba 2010) and revolves around studying theories (Dugassa 2012). Donnellon et al. (2014) contend that the 'about' approach may be inadequate for stimulating entrepreneurial intention arguing for the 'through' approach wherein students engage in real work by creating a new venture. Kyro (2005) also advocates the incubation of viable ideas into the educational process. Dugassa (2012) positions the teaching 'for' approach at developing and stimulating entrepreneurs. More specifically, teaching 'for' aims to develop the knowledge and skills of entrepreneurs (Lackeus 2015) and, therefore, is most relevant in programmes structured for the likes of incubators, short learning programmes and development programmes.

TABLE 3: Construct elements common to the $5 C$ 's framework and entrepreneurial performance model.

\begin{tabular}{|c|c|c|c|c|c|}
\hline \multirow{2}{*}{$\frac{\text { Variables }}{5 C^{\prime} \text { 's framework }}$} & \multicolumn{4}{|c|}{$E / P$ model } & \multirow{2}{*}{$\begin{array}{c}\text { Business plan } \\
\text { utilisation }\end{array}$} \\
\hline & Facilitator & Motivation & $\begin{array}{l}\text { Content } \\
(E / S, B / S)\end{array}$ & Approach & \\
\hline Conceptualisation & - & - & - & - & - \\
\hline Convictions & $x$ & $x$ & & $x$ & $x$ \\
\hline Competencies & - & - & $x$ & - & - \\
\hline Connections & - & - & - & $x$ & - \\
\hline Character & $x$ & $\mathrm{x}$ & - & - & - \\
\hline
\end{tabular}

$E / S$, entrepreneurial skills; $B / S$, business skills; $E / P$, entrepreneurial performance. 


\section{Methodology}

This article focuses on how entrepreneurship education is organised at traditional universities in South Africa. The 5C's framework is used to ascertain the structure and content of entrepreneurship education and thereafter, together with the $E / P$ model, is used to reconceptualise how entrepreneurship education could be best structured and taught. The research design was exploratory and quantitative in nature, involving secondary data. The South African public higher education landscape comprises 26 universities with 11 being considered traditional universities and the others being either comprehensive or universities of technology (UoTs). The population for this article comprised the traditional universities and all were included in the study. A limitation of this article is that UoTs and comprehensive universities were not included in this study. The reason for this was that an initial exploratory online search found that information required for this article was not available at the necessary level of detail required for many of the UoTs and comprehensive universities.

Entrepreneurship as an academic offering is normally housed within the faculties of commerce and/or management sciences. Thus, the online search strategy for the relevant information followed the following sequence: University website, Faculty of Commerce or Management Sciences, Year/handbook, undergraduate, postgraduate programmes. To execute a sweep of any relevant information that may have been missed using the abovementioned search strategy, the word 'entrepreneurship' was used as a keyword to search for relevant information using the search function in the respective universities' website. The search was executed during the period: February 2018 to April 2018.

The entrepreneurship offerings were quantified according to level of offering (undergraduate or postgraduate), intensity of offering (elective or specialisation), year in which offered and curriculum content. The content of the syllabi, as described in the syllabi section of the respective handbooks, within each entrepreneurship module was analysed using content analysis and compared against the competency element in the 5C's framework.

\section{Findings and discussion}

The findings with respect to the configuration of entrepreneurship education are summarised in Table 4 and are listed in order of the QS University World Ranking system.

It was found that none of the universities offers a module in entrepreneurship at the first-year undergraduate degree level. Rhodes University (RU), University of Fort Hare (UFH) and the University of the Western Cape (UWC) do not have any entrepreneurship offering at the undergraduate level. The University of Cape Town (UCT), University of KwaZulu-Natal (UKZN), University of Witwatersrand (WITS), University of Free State (UFS) and the University of Limpopo (UL) offer only one entrepreneurship module in the undergraduate programme. Stellenbosch University (SU) and the University of Pretoria (UP) offer two entrepreneurship modules at each of the second- and third-year levels. North-West University (NWU) offers three entrepreneurship modules at the secondyear level and one at the third-year level.

Despite the infusion of entrepreneurship modules into programmes, the percentage of credits for entrepreneurship modules to total programme credit, at best, plateaus around just 20\%. These findings confirm Musetsho and Lethoko's (2017) observation that many of the entrepreneurial curricula offered in different South African public universities are not their own and are not structured as a separate stand-alone degree, but are mostly designed as part of another business management qualification. It would therefore not be surprising if these students would want to pursue other careers in their chosen programme specialisations rather than entrepreneurship careers. The author readily acknowledges that students within other programmes with other areas of specialisation can become entrepreneurs and entrepreneurship modules would be helpful, but argues that this could be by circumstance rather than by design.

A different picture emerges at the postgraduate level. The University of Western Cape does not offer entrepreneurship at the postgraduate level. At Stellenbosch, entrepreneurship is offered as an elective at the postgraduate diploma or

TABLE 4: Configuration of entrepreneurship education at traditional South African universities.

\begin{tabular}{|c|c|c|c|c|c|c|c|c|}
\hline \multirow[t]{4}{*}{ QS institution } & \multicolumn{8}{|c|}{ 5C's element: Conceptualisation } \\
\hline & \multicolumn{7}{|c|}{ Academic } & \multirow{3}{*}{$\begin{array}{l}\text { Other } \\
\text { Centre, institutes, } \\
\text { incubators, short } \\
\text { courses }\end{array}$} \\
\hline & \multicolumn{4}{|c|}{$\begin{array}{l}\text { Number of entrepreneurship modules in undergraduate } \\
\text { degree programmes and year in which offered }\end{array}$} & \multirow[t]{2}{*}{$\begin{array}{l}\text { Honours } \\
\text { PGDip }\end{array}$} & \multirow[t]{2}{*}{$\begin{array}{l}\text { Master's/ } \\
\text { MBA }\end{array}$} & \multirow[t]{2}{*}{ PhD } & \\
\hline & 1st year & 2nd year & 3rd year & Credits & & & & \\
\hline 1 University of Cape Town (UCT) & None & 0 & 1 & $18 / 450$ & $S$ & $\mathrm{~S}$ & N/A & 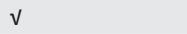 \\
\hline 2 University of the Witwatersrand (WITS) & None & 1 & 0 & $24 / 432$ & $\mathrm{~S}$ & $\mathrm{~S}$ & S & v \\
\hline 3 University of Pretoria (UP) & None & 2 & 2 & $(32+40) / 407$ & $S$ & $\mathrm{~S}$ & S & v \\
\hline 4 Stellenbosch University (SUN) & None & 2 & 2 & $(32+48) / 384$ & $E$ & N/A & N/A & v \\
\hline 6 University of KwaZulu-Natal (UKZN) & None & 1 & 0 & $16 / 416$ & $\mathrm{~S}$ & $\mathrm{~S}$ & S & $\checkmark$ \\
\hline 7 Rhodes University (RU) & None & None & None & $\mathrm{N} / \mathrm{A}$ & $\mathrm{S}$ & $E$ & $\mathrm{~N} / \mathrm{A}$ & $\mathrm{N} / \mathrm{A}$ \\
\hline 8 University of Western Cape (UWC) & None & None & None & 0 & N/A & N/A & N/A & $\checkmark$ \\
\hline 9 North-West University (NWU) & None & 3 & 1 & $(48+16) / 436$ & $\mathrm{~S}$ & $\mathrm{~S}$ & S & $v$ \\
\hline 10 University of the Free State (UFS) & None & 1 & 0 & $16 / 400$ & $\mathrm{~S}$ & $E$ & N/A & $v$ \\
\hline 12 University of Fort Hare (UFH) & None & None & None & N/A & N/A & $E$ & N/A & $v$ \\
\hline 13 University of Limpopo (UL) & None & 1 & None & N/A & $\mathrm{N} / \mathrm{A}$ & $\mathrm{S}$ & N/A & $v$ \\
\hline
\end{tabular}

E, Elective; S, Specialisation; N/A, not applicable. 
honours level, with no further specialisation thereafter. WITS, UP, UKZN and NWU offer a postgraduate specialisation in entrepreneurship up to the $\mathrm{PhD}$ level. The remainder of the universities offer entrepreneurship modules at the master's level, either as electives or as specialisation. The majority of universities have centres, institutes, incubators and short courses for entrepreneurship education that focus on business skills.

The above findings reveal the general nature of some entrepreneurship modules at the undergraduate level and specialisation at the postgraduate level with some form of centre or incubator that is focussed more towards business skills. These findings also confirm that entrepreneurship education is structured according to international 'best practice', as noted by Nieuwenhuizen et al. (2016) in their study. This type of 'top heavy' gearing goes against the grain of solving the unemployment problem through entrepreneurship education.

The author is also critical of the fostering of the 'best practice' approach and has reservations as to whether it is appropriate for entrepreneurship education in South Africa. The argument for the criticism is that the study by Nieuwenhuizen et al. (2016) is based on a review of programmes at universities located in Canada, the United Kingdom, China and the United States, within countries with robust economies. These aforementioned countries have GDPs ranging from 1.8 to about 20 trillion USD, compared to South Africa's 350 billion USD (World Bank 2019). It is argued that robust economies are more likely to present more opportunities for entrepreneurs to commercialise new products and services. Furthermore, their low unemployment rate, ranging from $3.9 \%$ to $5.6 \%$ (World Bank 2019), may have more to do with robust economies and less to do with the way entrepreneurship education is structured. If the argument does not hold true, then, by extension, if a country like South Africa follows the 'best practice' approach, which seems to be the case, then it should be able to churn out entrepreneurs to positively impact the unemployment rate. This is clearly not the case as the overall unemployment rate stands at $26.5 \%$ and, in particular, at 38.2\% for youth (Statistics South African 2017).

It would also be only natural and all too optimistic to recommend that a possible solution would be to intensify entrepreneurship education by infusing more entrepreneurship modules across programmes. To the contrary, the author is opposed to such an approach and puts forth the view, having taken cognisance of the views espoused by Professor Mthembu (Dell 2016) and Donnellon et al. (2014), that the structure of entrepreneurship education should be reconceptualised.

The results of the content analysis of the syllabi of entrepreneurship modules offered in undergraduate programmes at traditional universities in South Africa are presented in Table 5. The content has been analysed against the elements of competency of the 5C's framework.
TABLE 5: Competencies taught in entrepreneurship modules at traditional South African universities.

\begin{tabular}{lcccc}
\hline 5C's element: competency & All & Many & Few & None \\
\hline Opportunity recognition and assessment & $\mathrm{X}$ & - & - & - \\
Risk mitigation & - & $\mathrm{X}$ & - & - \\
Vision & - & - & $\mathrm{X}$ & - \\
Perseverance & - & - & - & $\mathrm{X}$ \\
Creativity & - & $\mathrm{X}$ & - & - \\
Resource leveraging & - & - & $\mathrm{X}$ & - \\
Value creation & $\mathrm{X}$ & - & - & - \\
Resilience & - & - & - & $\mathrm{X}$ \\
Self-efficacy & - & - & - & $\mathrm{X}$ \\
Network creation & - & - & $\mathrm{X}$ & - \\
Focus & - & $\mathrm{X}$ & - & - \\
\hline
\end{tabular}

All the universities include the elements of opportunity recognition and assessment and value creation in their syllabi. While many also included the elements of creativity, risk mitigation and focus, only few include vision, resource leveraging and network creation. However, none of them specifically focuses on the elements of perseverance, resilience and self-efficacy. While there seems to be focus on many of the correct competencies, the teaching approach predominantly used is the 'about' approach, with the rare exception of the 'through' approach being used by engaging students in projects and, in one case, live projects. According to the E/P model, when the approach is compromised, this has a diminishing effect on entrepreneurial performance. Given the descriptors in Table 2, many of the competencies may not be easily developed using the 'about' approach to teaching. The development of skills can be more easily enhanced in actual venture creation as espoused by Donnellon et al. (2014). It posited that the competency elements of perseverance, resilience and self-efficacy cannot be adequately developed by theory and actual venture creation would provide the ideal backdrop to the development of these competencies.

\section{Conclusion and recommendations}

The aim of this article was to explore how entrepreneurship education is structured in traditional universities in South Africa. Entrepreneurship education was measured against constructs in the $5 C^{\prime}$ 's framework and entrepreneurial model. The findings revealed the general nature of some entrepreneurship modules, with a low total credit value in relation to total programme credit value, at the undergraduate level and specialisation at the postgraduate level with some form of centre or incubator that is focussed more towards business skills. It was also found that at the undergraduate level, little attention is given to the development of entrepreneurial skills such as perseverance, resilience and self-efficacy.

It is recommended that the structure of entrepreneurship education be reconceptualised. The recommended framework, illustrated in Figure 1, reconceptualises entrepreneurship education having taken into consideration the parameters of the E/P model and underpinning of the 5C's framework, 


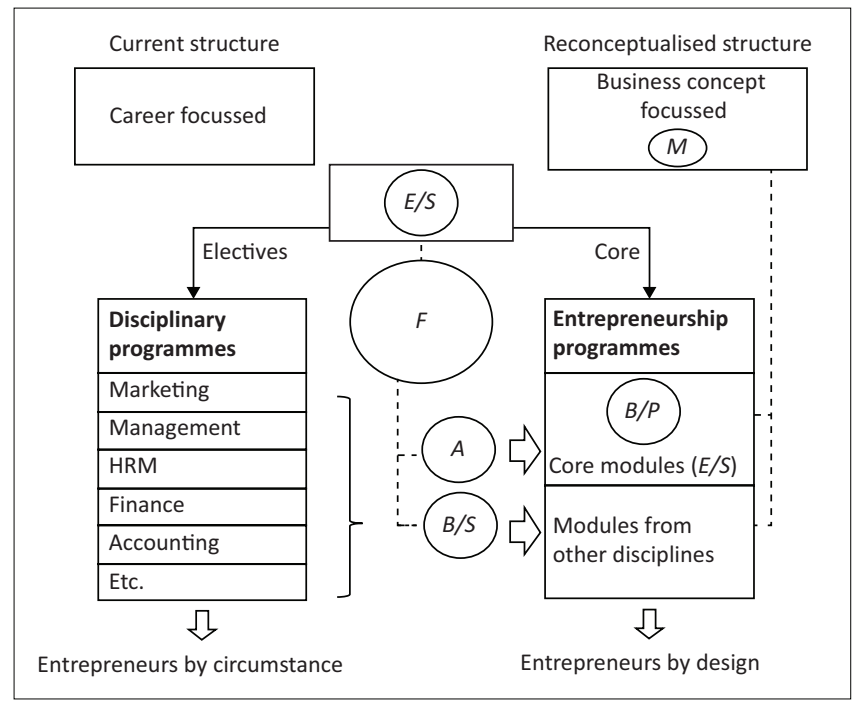

$E$, Elective; $S$, Specialisation; $E / P$, represents entrepreneurial performance; $F$, represents the abilities, skills and experience of the facilitator; $M$, represents motivation; $E / S$, represents entrepreneurial skills; $B / S$, represents business skills and knowledge; $A$, represents teaching approaches; $B / P$, represents business plan utilisation (part of learning approach); HRM, Human resrouce management.

FIGURE 1: Reconceptualised framework for entrepreneurship education.

as well as the views espoused by Professor Mthembu (Dell 2016) and Donnellon et al. (2014).

The key features of the reconceptualised entrepreneurship programme can be summarised as follows:

- Student intake could possibly be guided by competitions that funnel students who meet university entrance requirements and that have innovative business concepts into the programme. This speaks to the issue of student convictions in the 5C's framework and motivation (M) of the $E / P$ model.

- Selected students would study core entrepreneurship modules that aim to develop entrepreneurial skills $(E / S)$ as espoused in the $E / P$ model as well as competencies in the $5 C^{\prime}$ 's framework.

- The teaching approach $(A)$ should be the 'through' approach, which is facilitated by $B / P$ utilisation to translate the business concept into a business venture.

- Only those modules that are deemed to be appropriate to provide the knowledge and business skills $(B / S)$ that are immediately necessary to support the business venture that is to develop out of the business concept should be selected. These would be chosen from other disciplines and students would attend different sets of modules depending on the direction the business venture follows.

- The facilitator is deemed to be central to the programme, having the right conviction to ensure $E / S$ are developed using the teaching approach that affords learning 'through' the student's envisaged business ventures and to assist students in choosing appropriate modules from other disciplines relevant to each of their business ventures.

- The cohort size should be small because of the inherent complexities arising from the above mentioned demands on the facilitator.
- The major difference is that with the current structure, practice follows theory and in the reconceptualised structure theory is to follow practice by virtue of live projects. Instead of being exposed to the entire range of business skills as in traditional career-focussed programmes, the student selects to study the business skills relevant and necessary for his or her business venture. It is envisaged that post graduation, and as the business venture gains more traction, the student can attend programmes in existing incubators and development programmes to sharpen other business skills $(B / S)$ that become necessary as the business grows. The structure is considered to be 'flipped' as the current structure has entrepreneurship models embedded in career-focussed programmes, while the new entrepreneurship programme will have other relevant modules purposely selected to integrate into the entrepreneurship programme. Furthermore, by the time the student is ready to graduate, the business venture should be able to be scaled up and attract funding from existing government initiatives or even investors.

It is readily acknowledged that a number of administrative challenges will arise with regard to complexities inherent in timetabling for other modules as well as entrepreneurship modules within the context of a live project, administration and registration across disciplines, and the need for the programme to be structured in such a manner to meet the requirements for the award of an undergraduate degree. It is recommended that the reconceptualised programme be first piloted in tandem with the existing structure so that its effectiveness could be ascertained before scaling up.

It is also recommended that the study be extended to include the UoTs and comprehensive universities so that a more complete picture of the entrepreneurship education emerges. Given the challenge regarding inadequate secondary data mentioned earlier, primary research may be warranted.

\section{Acknowledgements Competing interests}

The views expressed in this article are the author's own and not the official position of the Durban University of Technology, where he was employed.

\section{Authors' contributions}

This article has sole authorship.

\section{Ethical considerations}

Ethical clearance is not required as the study involved secondary data that were publicly available.

\section{Funding}

This research received no specific grant from any funding agency in the public, commercial or not-for-profit sectors. 


\section{Data availability statement}

Data sharing is not applicable to this article as no new data were created or analysed in this study.

\section{Disclaimer}

The views and opinions expressed in this article are those of the authors and do not necessarily reflect the official policy or position of any affiliated agency of the author.

\section{References}

Abebe, A., 2015, 'Attitudes of undergraduate students towards self-employment in Ethiopian public universities', International Journal of Business and Management Review 3(7), 1-10.

Acs, Z.J. \& Armington, C., 2004, 'Employment growth and entrepreneurial activity in cities', Regional Studies 38, 911-917. https://doi.org/10.1080/0034340042000 280938

Adusei, M., 2016, 'Does entrepreneurship promote economic growth in Africa?', Africa Development Review 28(2), 201-214. https://doi.org/10.1111/1467 8268.12190

Audretsch, D.B., Keilbasch, M.C. \& Lehmann, E., 2006, Entrepreneurship and economic growth, Oxford University Press, Oxford.

Baumol, W.J., 2014, 'Stimulating growth amid recession: Entrepreneurship, innovation and the Keynesian revolution', Journal of Policy Modelling 36, 629-635. https:// doi.org/10.1016/j.jpolmod.2014.03.004

Berkowitz, D. \& Dejong, D.N., 2005, 'Entrepreneurship and post-socialist growth', Oxford Bulletin of Economics and Statistics 67(1), 25-46. https://doi.org/10.1111/ j.1468-0084.2005.00108.x

Bjuggren, C.M., Johansson, D. \& Stenkula, M., 2012, 'Using self-employment as proxy for entrepreneurship: Some empirical caveats', International Journal of Entrepreneurship and Small Business 17(3), 290-303. https://doi.org/10.1504/ IJESB.2012.049578

Carree, M. \& Thurik, R., 2008, 'The lag structure of the impact of business ownership on economic performance in OCED countries', Small Business Economics 30 101-110. https://doi.org/10.1007/s11187-006-9007-0

Celuch, K., Bourdeau, B. \& Winkel, D., 2017, 'Entrepreneurial Identity: The missing link for entrepreneurial education', Journal for Entrepreneurship Education 20(2), $1-20$.

Centre for Entrepreneurial Excellence, 2014, The National Survey of entrepreneurship education: An overview of 2012-2014 survey data, George Washington University Centre for Entrepreneurial Excellence, Washington, DC.

Chang, J. \& Rieple, A., 2013, 'Assessing students' entrepreneurial skills development in live projects', Journal of Small Business and Enterprise Development 20(1) 225-241. https://doi.org/10.1108/14626001311298501

Chinyamurindi, W.T., 2016, 'A narrative investigation on the motivation to become an entrepreneur among a sample of black entrepreneurs in South Africa: Implication for entrepreneurship career development education', Independent Research Journal in the Management Sciences 16(1), 1-9. https://doi.org/10.4102/ac. v16i1.310

Chimucheka, T., 2014, 'Entrepreneurship education in South Africa', Mediterranean Journal of Social Sciences 52(2), 403-416. https://doi.org/10.5901/mjss.2014. v5n2p403

Co, M.J. \& Mitchell, B., 2006, 'Entrepreneurship education in South Africa: A nationwide survey', Education + Training 48(5), 348-359. https://doi.org/10.1108/
00400910610677054

Collet, H., 2013, 'Entrepreneurship education in higher education: Are policy makers expecting too much?', Education and Training 55(8), 836-848. https://doi. oxpecting too much?', Educatic

Dees, J.G., Haas, M. \& Hass, P., 1998, The meaning of social entrepreneurship, Kauffman Centre for Entrepreneurial Leadership and Graduate School of Business, Stanford University, Stanford, CA.

Dell, S., 2016, 'Building innovation, entrepreneurship in universities', University World News, 16 September 2016, p. 1-4.

Donnellon, A., Ollilia, S. \& Middleton, K.W., 2014, 'Constructing entrepreneuria identity in entrepreneurship education', The International Journal of Managemen Education 12, 490-499. https://doi.org/10.1016/j.ijme.2014.05.004

Drucker, P.F., 1985, Innovation and entrepreneurship, Harper and Row, New York.

Dugassa, T.G., 2012, 'The context of entrepreneurship education in Ethiopian universities', Management Research Review Journal 25(3), 225-244. https://doi. org/10.1108/01409171211210136

Farrington, S., Gray, B. \& Sharp, G., 2011, 'Perceptions of an entrepreneurial career Do small business owners and university students concur?', Management Dynamics 20(2), 2-17.

Fatoki, O.O., 2010, 'Graduate entrepreneurial intention in South Africa: Motivations and obstacles', International Journal of Business Management 5(9), 87-98. https://doi.org/10.5539/ijbm.v5n9p87

Folster, S., 2000, 'Do entrepreneurs create jobs?', Small Business Economics 14(2), 137-148. https://doi.org/10.1023/A:1008141516160
Fritsch, M., 2008, 'How does new business formation affect regional development? Introduction to the special issue', Small Business Economics 30(1), 1-14. https:// doi.org/10.1007/s11187-007-9057-y

Global Entrepreneurial Monitor, 2017, South Africa report 2016/2017, can small business survive in South Africa? GEM, Cape Town.

Isah, U.G. \& Garba, A.S., 2015, 'Analysis of student's attitudes toward self-employment intention in tertiary institution in Nigeria', International Journal of Small Business and Entrepreneurship Research 3(3), 1-11.

Johnson, D., 2001, 'What is innovation and entrepreneurship? Lessons for large organisations', Industrial and Commercial Training 33(4), 135-140. https://doi. org/10.1108/00197850110395245

Kabonga, J. \& Okpara, J.O., 2010, 'Entrepreneurship education in sub-Saharan African universities', International Journal of Entrepreneurial Behaviour and Research 16(4), 296-330. https://doi.org/10.1108/13552551011054499

Kirzner, I.M., 1978, Competition and entrepreneurship, University of Chicago Press, Chicago, IL.

Kuratko, D.F., 2005, 'The emergency of entrepreneurship education: Development, trends and challenges', Entrepreneurship Theory and Practice 29(5), 577-597. https://doi.org/10.1111/j.1540-6520.2005.00099.x

Kyro, P., 2005, 'Entrepreneurial learning in a cross-cultural context challenges previous learning paradigms', in P. Kryo \& C. Carrier (eds.), The dynamics of learning entrepreneurship in a cross-cultural university context, p. 68-102, University of Tampere, Hameenlinna.

Lackeus, M., 2015, Entrepreneurship in education, what, why, when, how? Entrepreneurship 360 Background Paper, OECD, EU, Paris, France.

Lebusa, M.J., 2011, 'Does entrepreneurial education enhance under-graduate students' entrepreneurial self-efficacy? A case at one university of technology in South Africa', China-USA Business Review 10(1), 53-64.

Littlewoo, D. \& Holt, D., 2018, 'Social entrepreneurship in South Africa: Exploring the influence of environment', Business and Society 57(3), 525-561. https://doi. org/10.1177/0007650315613293

Morris, M.H. \& Kuratko, D.F., 2014, 'Building university 21st century entrepreneurship programs that empower and transform', in S. Hoskinson \& D.F. Kuratko (eds.), Innovative pathways for university entrepreneurship in the 21st century, advances in the study of entrepreneurship, innovation and economic growth, vol. 24, pp. 1-24, Emerald Publishing Limited, Bingley, UK.

Muofhe, N.J. \& Du Toit, W., 2011, 'Entrepreneurial education's and role models influence on career choice', South African Journal of Human Resource Management 9(1), 1-15. https://doi.org/10.4102/sajhrm.v9i1.345

Musetsho, T.R. \& Lethoko, M.X., 2017, 'An evaluative study on the effect of entrepreneurial education curriculum on students at the University of Venda, South Africa', The Independent Journal of Teaching and Learning 12910, 74-89.

Mwasalwiba, E.S., 2010, 'Entrepreneurship education: A review of its objectives, teaching methods, and impact indicators', Education + Training 52(1), 20-47. https://doi.org/10.1108/00400911011017663

National Planning Commission, 2012, National development plan 2030: Our futuremake it work, South African Government, Pretoria.

Nel, H. \& Neale-Shutte, M., 2013, 'Examining the evidence: Graduate employability at NMMU', South African Journal of Higher Education 27(2), 437-453.

Nieuwenhuizen, C., Groenwald, D., Davids, J., Van Rensburg, L.J. \& Schachtebeck, C., 2016, 'Best practice in entrepreneurship education', Problems and Perspectives in Management 14(3), 528-537. https://doi.org/10.21511/ppm.14(3-2).2016.09

Oluseye, A.M., Adebayo, K.F., Olulanu, O.I., Adesola, O.O. \& Omonike, A.O., 2017 'Effect of Entrepreneurship education on self-employment initiatives among Nigerian Science and Technology students', Journal of Education and Practice 8(15), 44-51.

Panagiotis, P., 2012, 'Could higher education programs, culture and structure stifle the entrepreneurial Intentions of students?' Journal of Small Business and Enterprise Development 9(3), 461-483. https://doi.org/10.1108/14626001211250162

Pittaway, L. \& Edwards, C., 2012, 'Assessment: Examining practice in entrepreneurship education', Education + Training 54(8), 778-800. https://doi.org/10.1108/00400 911211274882

Pretorius, M., Nieman, G. \& Van Vuuren, J., 2005, 'Critical evaluation of two models for entrepreneurship education', International Journal of Education and Management 19(5), 413-427. https://doi.org/10.1108/09513540510607743

Prior, A., 2014, 'What college can teach the aspiring entrepreneur?', The Wall Street Journal 1.

Rietvel, C.A., Hessels, J. \& Zwan, P., 2014, 'The stature of self-employed and its premium', Tinbergen Institute Discussion Paper T122014-109/VII.

Robinson, D.A., 2002, 'A phenomenological study of how entrepreneurs experience and deal with ethical dilemmas', PhD thesis, Rhodes University, Grahamstown.

Sandhu, M.S., Jain, K.K. \& Yusof, M., 2010, 'Entrepreneurial inclination of students at a private university in Malaysia', New England Journal of Entrepreneurship 13(1) 61-72. https://doi.org/10.1108/NEJE-13-01-2010-B005

Schlaegel, C. \& Koenig, M., 2014, 'Determinants of entrepreneurial intent: A metaanalytic test and integration of competing models', Entrepreneurship Theory and Practice 38(2), 291-332. https://doi.org/10.1111/etap.12087

Schumpeter, J.A., 1934, The theory of economic development, Harvard University Press, Cambridge, MA.

Skosana, V. \& Urban, B., 2014, 'Entrepreneurial intentions at further education and training colleges in South Africa', South African Journal of Higher Education 28(4), $1-14$. 
Statistics South Africa, 2017, Quarterly labour force survey: Quarter 4, Government Press, Pretoria, South Africa.

Swedberg, R., 2002, Entrepreneurship: The social science view, Oxford University Press, Oxford, UK.

Urban, B., 2011, The entrepreneurial mind-set (book 2: Perspectives in entrepreneurship: A research companion), Pearson Education, Cape Town.

Urban, B. \& Richard, P., 2015, 'Perseverance among university students as an indicator of entrepreneurial intent', South African Journal of higher Education 29(5), 263-278. https://doi.org/10.20853/29-5-528
Von Mises, L., 1951, 'The use of knowledge in society', The American Economic Review 35(4), 519-530.

World Economic Forum, 2011, Unlocking entrepreneurial capabilities to meet the global challenges of the 21st century: Final report on the entrepreneurship education workstream, World Economic Forum Global Education Initiative, Geneva, Switzerland.

World Bank, 2019, World development indicators, World Bank, viewed 05 February 2019, from https://data.worldbank.org/country/south-africa.

Zhang, D., 2017, 'Investigating the perception of university entrepreneurship education', Journal of Entrepreneurship Education 20(2), 1-18. 